\title{
Determinants of transaction activity in commercial real estate markets: evidence from European and Asia-Pacific countries
}

Article

Accepted Version

Devaney, S., McAllister, P. and Nanda, A. (2017) Determinants of transaction activity in commercial real estate markets: evidence from European and Asia-Pacific countries. Journal of Property Research, 34 (4). pp. 251-268. ISSN 1466-4453 doi: https://doi.org/10.1080/09599916.2017.1383931 Available at https://centaur.reading.ac.uk/72747/

It is advisable to refer to the publisher's version if you intend to cite from the work. See Guidance on citing.

To link to this article DOI: http://dx.doi.org/10.1080/09599916.2017.1383931

Publisher: Routledge

All outputs in CentAUR are protected by Intellectual Property Rights law, including copyright law. Copyright and IPR is retained by the creators or other copyright holders. Terms and conditions for use of this material are defined in the End User Agreement.

www.reading.ac.uk/centaur 
Central Archive at the University of Reading

Reading's research outputs online 


\title{
Determinants of Transaction Activity in Commercial Real Estate Markets: Evidence from European and Asia-Pacific Countries
}

\begin{abstract}
Variations in transaction activity between commercial real estate markets could have important implications for investment strategies and pricing. We consider why turnover rates, a common liquidity proxy, vary between countries and over time. We examine 38 countries in Europe and Asia-Pacific over the period 2000-2014. A conceptual framework is discussed prior to estimation of panel models that use turnover rates as the dependent variable. Our results indicate that the size and wealth of a country, the risk associated with that country and the performance of its commercial real estate market are significant factors that explain transaction activity. The quality of property rights is also an important factor.
\end{abstract}

\section{Keywords}

Commercial real estate; liquidity; transaction activity; turnover rates. 


\section{Introduction}

The growth in cross-border direct real estate investment activities over the last two decades has meant that real estate investors are increasingly exposed to the challenges and costs of sourcing, acquiring, pricing, managing and disposing of real estate assets outside their domestic market. Yet, despite these trends, there has been little published research on cross-country liquidity issues in private real estate markets. There are major variations in the liquidity and trading activity of different asset classes and, within an asset class, there can be significant differences over time and between markets and assets. In this context, transaction volumes and turnover rates are often used as (albeit imperfect) proxies for market liquidity. In private real estate markets, the level of transaction activity tends to be closely related to the prevailing market conditions, number of market participants and other variables such as market maturity and size. We investigate variations in transaction activity between different national commercial real estate markets in Asia-Pacific and Europe.

Largely owing to limited availability of data, the limited research on trading volumes and transaction activity in private real estate markets has focussed on the US. Cross-country research has been hampered by inconsistent and partial data at both city and country level. Whilst data on international transaction volumes has improved considerably in the last two decades, data on the stock and performance of commercial real estate has expanded more slowly. The central research questions for this study are how and why turnover varies over time and between different commercial real estate markets. The empirical research uses data on trading volumes and turnover rates compiled by DTZ (now merged with Cushman \& Wakefield). The data combine information on transaction activity for a wide range of countries with proprietary estimates of the value of the total real estate invested stock in those countries. 
In addition, for a subset of countries, estimates of turnover rates for the office sector have been examined separately.

We develop a conceptual framework to understand potential determinants of turnover rates and then estimate econometric models based on this framework that use turnover rates as the dependent variable. We find that the size and wealth of a country, together with the performance of its commercial real estate market, are significant drivers of turnover rates. Furthermore, the quality of property rights in a country is a significant factor. Findings for the office sector are broadly consistent with the findings for all commercial property. The rest of this paper is structured as follows. In the next section, we review relevant theory and empirical studies that have considered the drivers of transaction activity in commercial real estate markets. In the third section, we examine the turnover rates supplied by DTZ as well as the other data collected for this study. In section four, we set out details of the econometric models that are applied before turning to discussion of the results from estimation of such models in section five. A final section then concludes.

\section{Liquidity, transaction activity and investment performance in commercial real} estate markets

In the major asset classes, measures of transaction activity are often the simplest and most widely available indicators of market liquidity. When assessing market conditions, changes in transaction activity are often used as indicators of changes in liquidity. At its core, the liquidity of an asset is the capacity to be able to immediately exchange it for cash at current market prices at no cost. Hence, three core measures of liquidity are time-to-transact, cost-to-transact and certainty of market price. One common consequence of low liquidity is reduced 
transaction activity. Constantinides (1997) stressed the trade-off between transactions costs, transaction activity and asset pricing, arguing that the effect of transaction costs may be deflected to transaction frequency rather than affecting prices.

However, such relationships are by no means axiomatic. Buyers and sellers can have different perspectives on the liquidity of a market. Fisher, Gatzlaff, Geltner and Haurin (2004) pointed out that transaction activity may be low in a market not because assets are difficult to sell, but rather because existing investors prefer to hold at current price levels. For example, in socalled 'core' markets, though investor demand is high, the marginal investors tend to invest in long term holds. For institutional grade real estate, buyers and sellers may have quite different perspectives on the liquidity of such markets. As a result, commercial real estate markets that might be regarded as relatively liquid by asset owners can have below average turnover rates.

Yet there are several stylized facts regarding the relationship between transaction activity and investment performance in commercial real estate markets. In terms of variation over time, "hot" phases in the real estate cycle tend to be periods when prices are rising, average selling times are relatively short, and transaction activity is higher than average. "Cold" phases in the real estate cycle have the opposite characteristics: prices are falling, time-to-transact is longer and transaction activity is lower than average (Krainer, 2001). Fisher, Gatzlaff, Geltner and Haurin (2003) contended that in private asset markets such as real estate, changes in market conditions are signaled by both changes in prices and changes in transaction activity. More formally, they provide a search-based model that demonstrates how both prices and volumes are influenced by shifts in buyer and seller pricing behavior (see also Goetzmann and Peng, 2006). 
Since changes in transaction activity are widely used as a proxy for liquidity in the absence of alternative measures, there has been interest in what the determinants of such activity are, i.e. what influences the number and behavior of buyers and sellers that leads, in turn, to the volumes that we observe? The literature on the relationship between returns/prices and transaction flows suggests some determinants of transaction activity (Fisher, Ling and Naranjo, 2009; Ling, Marcato and McAllister, 2009). Whilst a positive contemporaneous correlation between price changes and volume may be a stylized empirical fact in the equities market, there is longstanding skepticism about whether there is a causal relationship (see Gallant, Rossi and Tauchen, 1992). A contemporaneous positive relationship might be because flows and returns are jointly dependent on common economic determinants.

In their review of the drivers of private real estate liquidity, focused mostly on temporal variation, Clayton, MacKinnon and Peng (2008) present a range of potential determinants of variation in transaction activity. Rooted in the behavior of market participants, at the core of their theoretical analysis is variation in buyers' and sellers' valuations. As in Fisher et al. (2003), it is expected that transaction frequency will be positively related to the level of overlap in buyers' and sellers' valuations. In 'hot' markets, buyers are expected to be more likely to have higher valuations than sellers. In 'cold' markets, the probability of buyers' valuations being above sellers' is expected to be lower. As a result, in 'cold' markets, there is a lower propensity for trades to occur and transaction activity drops. A range of factors that may affect deviations between buyer and seller valuations such as appraisal smoothing, disposition bias, pro-cyclical credit markets, clientele effects and option values are discussed (see also Anglin, Rutherford and Springer, 2003; Ortalo-Magné and Rady, 2006.)

While there has been a body of work investigating the dynamic relationship between 
transaction activity and investment returns in commercial real estate markets, the crosssectional determinants of transaction activity have been largely neglected. It is expected that differences in transaction activity between markets will reflect differences in market institutions and broader economic conditions. However, causal relationships between the determinants of transaction activity (and the determinants of the determinants) tend to be complex with direct and indirect effects, mediated and moderated interactions, and bidirectional and feedback relationships present. The main market-level attributes are expected to be a range of interrelated variables such as information availability, market transparency and maturity, the quantity of investable stock, the quality of brokerage and other transaction support services, direct and indirect transaction costs, and other institutional factors. These variables are expected to be important determinants of the quantity of potential buyers and sellers and of their propensity to transact.

Notwithstanding that the relationship between investment performance and transaction activity is theoretically and empirically uncertain, they tend to be closely linked. Whilst macro-economic and capital market drivers (such as economic growth, global integration, quality of institutions, current account balance, depth of savings markets, debt availability, etc.) are expected to affect each other and the real estate market, real estate performance is also expected to influence the macro-economy and capital markets, albeit more indirectly and less extensively. Clearly, different markets will have different economic structures and trajectories. Market maturity will vary as market depth, information availability, and so on, varies. Whilst market maturity is expected to be an important determinant of transaction activity, it is perhaps less obvious that transaction activity will also be a factor determining market maturity. 
In line with the discussion above, a market's level of transaction activity is assumed to be positively related to real estate investment performance and vice versa. Investment performance is then expected to be determined by a range of real estate market, economic and capital market variables. A number of expected causal relationships can be identified and are presented schematically in Figure 1. As a determinant of performance, it is presumed that there will be a positive relationship between economic growth and market transaction activity. Mainly due to its effects on the number of buyers and sellers, the size of the institutional investment market is expected to be positively associated with transaction activity as well. All else equal, primarily through the increased presence of cross-border investors, a positive relationship between a market's global economic integration and the level of transaction activity is expected. In a similar vein, it is anticipated that there will be a positive association between the quality of economic institutions (rule of law, ease of doing business, corruption ratings, etc.) and transaction activity.

\section{INSERT FIGURE 1 HERE}

Capital market indicators e.g. sovereign bond yield spreads, are commonly used as a proxy for investor risk perceptions. It is expected that there will be a negative relationship between risk perceptions and transaction activity. Debt availability may increase the number of potential buyers and has been identified as a significant determinant of capitalisation rates (see Chervachidze and Wheaton, 2013). A positive relationship between debt availability and transaction activity is expected. Meanwhile, the current account balance has not been included in previous models of commercial real estate markets. Here, it is meant to control for the effects of global imbalances in trade on local real estate market performance. In particular, it is expected that so-called 'surplus countries' such as Germany, Switzerland, 
Japan and major oil exporters have low levels of transaction activity in their domestic real estate investment markets owing to a combination of relatively high prices and low investor propensity to sell. Hence, a negative relationship is expected between current account balance and commercial real estate transaction activity.

Turning to real estate market variables, it is a stylized fact that direct or explicit transaction costs (taxes, brokerage fees, settlement costs and periods etc.) and indirect or implicit transaction costs (search costs, price impact effects, regulation etc.) have a negative effect on transaction activity. Direct transaction costs are relatively straightforward to measure, but indirect transaction costs are less tangible. Real estate market maturity is expected to act as a portmanteau variable that captures many indirect costs. Keogh and D'Arcy (1994) conceptualise market maturity in terms of the scope of real estate occupational and investment 'products', market responsiveness to demand, the presence of an established real estate profession with associated institutions and networks, the extent of information flows and research activity, market openness and standardization of property rights and market practices. This framework has been subsequently adopted and extended in research on both European and Asia-Pacific markets (for example, McGreal, Parsa and Keivani, 2002; Chin and Dent, 2005; Chin, Dent and Roberts, 2006). A positive relationship is expected between real estate market maturity and transaction activity.

Indirect costs are also related to theoretical expectations regarding market size. In sectors that are characterised by scale economies and opaqueness, it is expected that investment will be more concentrated because of information networks. Information availability stimulates initial investment and initial investment generates more information, which generates path 
dependency effects and results in informational cascades. Owing to such information network effects, a positive relationship is expected between market size and transaction activity.

In a study of US markets, Devaney, McAllister and Nanda (2017) drew upon data on trading volumes and turnover rates for 49 US MSA office markets. Panel models were employed to test which factors led to higher or lower turnover over the period 2001-2015. They found that turnover rates were positively related to market size and economic growth rates. However, the results also indicated that there were variations in the size of these effects between different categories of investor. Consistent with information network effects, institutional investment was more concentrated in large metro areas; the market size had a stronger positive effect on trading levels compared to investment by private buyers. A negative relationship with vacancy rates supported the observations of previous research that trading is pro-cyclical with regard to real estate market conditions. Meanwhile, a negative coefficient for the spread between corporate and government bond yields suggested that trading activity was also sensitive to changes in risk. Often the largest direct transaction cost, turnover rates were found to be lower in those office markets where transfer taxes were higher.

Modelling of commercial real estate trading volumes across a wide range of national real estate markets has been conducted by Lieser and Groh (2014). They set their work in the context of the attractiveness of markets to international real estate investors. In this paper and in an earlier article (Lieser and Groh, 2011), they assembled data on a range of indicators that might affect international investor decisions on where to invest. This included measures of economic activity, the scale and potential for real estate market growth, capital markets, legal and regulatory factors, and the wider social and political environment. The dependent variable in 
this work appears to be total transaction volume per year, including domestic and international real estate investor activity, for 47 different countries.

Lieser and Groh (2014) regressed data on volumes on to composite indicators for the factors listed above. This revealed volumes to be driven by the scale of real estate markets, the depth of capital markets and the legal and regulatory environment. Taking each factor in turn, volumes were also regressed on to raw data for the indicators that made up the composite indices. Most of this modelling was carried out on data for the period 2004-2009. Although their work is useful in drawing attention to a wide range of data sources capturing economic activity and the investment environment, there are some issues. As pointed out by Mauck and Price (2017), a major issue is the mismatch between the focus of the conceptual framework (on cross-border activity) and the nature of the variable being modelled (total transaction activity). Another issue is the omission of any variables relating to real estate market conditions in the countries concerned.

In summary, transaction activity is an important indicator of commercial real estate market conditions. Although intrinsically linked to liquidity, liquidity is a more multifaceted concept whose measurement is elusive. A positive relationship is expected between the level of transaction activity and market liquidity. It is a stylized fact that transaction activity tends to decrease when buyers' and sellers' asset valuations diverge, but low levels of transaction activity do not necessarily indicate low liquidity. Transaction activity is expected to vary between markets because of differences in direct transaction costs, maturity, size, market conditions and other institutional structures. Below, we investigate formally whether empirical evidence is consistent with the expected relationships set out above. 


\section{Data}

Data on annual turnover rates for the period 2000 to 2014 were provided by DTZ (now merged with Cushman \& Wakefield) for 38 countries and territories in the Europe and Asia-Pacific regions. This represents all the markets for which these rates were compiled. The turnover rates measured the value of commercial real estate transactions in each country in any given year as a proportion of the value of the invested property stock. DTZ compiled data on investment transactions of over $€ 1$ million in Europe and US \$5 million in Asia-Pacific. Meanwhile, the invested stock figures were DTZ research estimates of the value of investment grade real estate held by professional investors in each country. Such investors include insurance companies, pension funds, REITs, public and private property companies, and unlisted vehicles such as open- and closed-end real estate funds. These stock figures are discussed further in DTZ (2015).

The turnover rates and stock estimates supplied by DTZ related to all types of commercial real estate and were not disaggregated by sector. To develop the analysis further and provide a closer match to the real estate market indicators discussed below, an attempt to measure office sector turnover rates was made. DTZ reported office transaction volumes for 28 out of the 38 countries in the sample. ${ }^{1}$ However, a set of stock figures for the office sector was not available. Instead, DTZ provided estimates of the share of that sector within the total stock as at 2014. We have used this information to create office stock figures for 2014 and for earlier years on the assumption that the share of offices within the total stock was stable over the period studied.

\footnotetext{
${ }^{1}$ Most of the countries omitted from the office transaction data were relatively small markets, e.g. Estonia, Latvia, Lithuania, Greece and Ukraine.
} 
Together with the data on volumes, these figures enabled measurement of office sector turnover rates in each country.

The assumptions used to create office turnover rates are not ideal and illustrate the difficulties in making cross-country comparisons where national markets differ in transparency and data availability. MSCI were a possible alternative source of data on the composition of the real estate investment market, but their indices cover a smaller number of countries and do not cover all professional investors. Therefore, we proceeded with our own estimates, but recognise that our assumption of offices being a set share of the total stock through time is a strong assumption, particularly for emerging real estate markets. ${ }^{2}$ Yet our later results on the determinants of transaction activity for offices are very consistent with those for all property.

The literature review noted the importance of real estate investment performance in affecting trading activity. Although the availability of total, income and capital return measures for private real estate in different countries has improved over time, there are still significant gaps, particularly for countries in the Asia-Pacific region. As a substitute, we obtained indicators of prime office rents, vacancy rates and capitalization rates from DTZ, offices being the sector for which market data was consistently available. Matching these indicators to data on turnover rates was complicated by the fact that market indicators were compiled for individual cities, not countries. So estimates for the cities within each country had to be weighted to produce a composite series for each country. ${ }^{3}$ Again, this is not ideal, but considered a necessary step given the importance of real estate performance within our conceptual framework, which makes the inclusion of a proxy measure highly desirable.

\footnotetext{
${ }^{2}$ The IPD global index published by MSCI shows a slow downward trend in the share of offices in their indices between 2001 and 2007, followed by a fairly stable share from 2007 onwards (MSCI, 2015).

${ }^{3}$ We performed this weighting using office floorspace figures for the cities concerned, with larger markets thereby having the greatest weight.
} 
Table 1 lists the countries covered by the study and reports average turnover rates and stock estimates in each case. It also reports the average office vacancy rate and capitalization rate over the period. This gives a sense of how the countries differ in terms of transaction activity and office market fundamentals. The figures indicate that Sweden, the UK and Singapore have the highest average turnover rates when considering commercial real estate overall. In all countries, turnover rates appear to be higher for offices, which would match expectations given that offices are a common target for international investors. Developed markets appear to have higher turnover rates than emerging markets, but there are notable exceptions. For instance, the transition economies of Poland and Czech Republic have high turnover rates for offices, while Switzerland and Japan are ostensibly developed markets where overall transaction activity seems muted.

\section{INSERT TABLE 1 HERE}

The national averages hide the fact that some countries had very high turnover rates at the peak of the real estate investment market in 2007. In that year, China, India, Russia, Sweden, Belgium, Germany and Poland had office turnover rates of between $15 \%$ and $20 \%$, while Singapore and the Czech Republic had rates in excess of $20 \%$. There were also major variations in performance over the period. This is summarised at an aggregate level by Figures 2 and 3, which show the correspondence between office capitalization rates and office turnover rates for Europe and Asia-Pacific, respectively. The period begins at the time of the stock market corrections associated with the 'dot.com bust'. There was a positive association between pricing and transaction activity in the years leading up to the Global Financial Crisis (GFC), 
while the GFC was associated with large falls in activity and increases in capitalization rates. This cycle is particularly marked for the set of European markets.

\section{INSERT FIGURE 2 HERE}

\section{INSERT FIGURE 3 HERE}

In terms of other variables identified in our review, we undertook an extensive search for appropriate data. The World Bank and IMF online datasets were used to obtain time series that tracked economic growth, scale and wealth in each country (using GDP and GDP per capita in USD terms and real GDP growth rates), current account balances, FDI flows and domestic credit (all as expressed as percentages of GDP), and inflation rates. ${ }^{4}$ We also measured the country risk premium for as many countries in the sample as possible. This was done by calculating for each year the spread between ten-year government bond yields and the equivalent US benchmark bond yields in that year. While these sources are fairly comprehensive, there are gaps in individual years for some countries that restricted the estimations which follow, either by causing observations to be dropped or some variables to be omitted.

Table 2 reports average GDP and GDP per capita for each country in the sample, as well as the averages for bond yield spread, current account balance and net inward FDI variables. There is a big dispersion in terms of economic scale and wealth, and the size of the invested real estate stock does not mirror perfectly the economic size of each economy. Average bond spread

\footnotetext{
${ }^{4}$ The main exception in terms of sources was the case of Taiwan where comparable data had to be obtained from local statistical agencies.
} 
broadly captures country risk and, for most countries, is around zero or positive, with Russia and Turkey having the largest spreads over US government bonds. However, Japanese and Swiss bonds had lower yields on average than the US. Large current account surpluses are evident for Singapore, Norway and Switzerland while the biggest deficits in this period were in Portugal and Greece. Net inward FDI has a positive average for all markets and is positive on average for all years, even the GFC years.

\section{INSERT TABLE 2 HERE}

Finally, as well as economic variables, we are interested in how the institutional environment for commercial real estate investment varies between countries. A range of measures that focus either on economic openness or, more directly, property rights in different countries are released regularly by organisations such as the World Bank, Transparency International, and The Heritage Foundation. We use the Index of Economic Freedom compiled by The Heritage Foundation as it provides a consistent time series from 2000 to 2014 for the countries in our sample. ${ }^{5}$ This index is comprised of a number of sub-indexes that measure investment freedom and property rights. These sub-indexes are highly correlated with the main index and also with GDP per capita, leading us to orthogonalise the latter variable during the modelling process. The indexes are also somewhat correlated with the country risk premium measure.

\section{Econometric Model}

Drawing upon well-established econometric procedures, we test the influence of a range of potential determinants for transaction activity by regressing national-level economic and real

\footnotetext{
${ }^{5}$ See www.heritage.org/index for more information, last accessed in February 2017.
} 
estate indicators on to turnover rates, exploring the rates for all investment property and for office property separately. We use a standard fixed effects panel model of the following form:

$$
p_{i t}=\alpha+\beta_{1} X_{i t}+\beta_{2} Z_{i t}+\delta_{i}+\omega_{i t}
$$

Where $p_{i t}$ is the turnover rate in nation $i$ in year $t, X_{i t}$ is a vector of national economy attributes and $Z_{i t}$ is a vector of real estate market attributes (e.g. stock, vacancy rates) of nation $i$ in year t. $\delta_{\mathrm{i}}$ are country-specific dummy variables and $\omega_{\mathrm{it}}$ is the idiosyncratic error.

This approach was preferred to pooled OLS because there is likely to be significant unobserved heterogeneity at the country level. In this specification, heterogeneity is assumed to be constant over time and correlated with the observable factors. The constant effect is removed by meandifferencing the data. This estimation strategy is consistent with theoretical expectations that market-specific unobserved characteristics can bring in a permanent shift in commercial real estate indicators such as turnover rates across markets. A further advantage of this method is that it allows us to utilise both time series and cross sectional variations in the data, which increases the efficiency of the OLS estimates. We envisage that fixed effect modelling may be more appropriate than random effect modelling owing to presence of a small number of crosssections in this dataset.

Our theoretical discussion indicates several variables that can capture the variation in turnover rates across markets. A key concern in incorporating all of these variables is that there may be strong inter-relationships between them, giving rise to a potential problem of multicollinearity. In the presence of multicollinearity, the interpretation of individual coefficients becomes problematic owing to difficulties in separating the individual contributions. Therefore, it is 
advisable to have a parsimonious specification of the model without loss of information on several dimensions of the research hypothesis. With this goal, we specify a model that is relatively parsimonious, yet captures the main confounding factors as indicated below:

$$
\begin{aligned}
\mathrm{p}_{\mathrm{it}}= & \alpha_{0}+\beta_{1} \log \left(\operatorname{stock}_{\mathrm{it}}\right)+\beta_{2} \log \left(\mathrm{gdpc}_{\mathrm{it}}\right)+\beta_{3} \mathrm{vac}_{\mathrm{it}}+\beta_{4} \mathrm{spr}_{\mathrm{it}}+\beta_{5} \mathrm{fdi}_{\mathrm{it}}+\beta_{6} \mathrm{bop}_{\mathrm{it}}+\beta_{7} \mathrm{ipr}_{\mathrm{it}} \\
& +\beta_{8} \mathrm{gfc}_{\mathrm{it}}+\delta_{\mathrm{i}}+\omega_{\mathrm{it}}
\end{aligned}
$$

Where $p_{i t}$ is the turnover rate, $\log \left(\right.$ stock $\left._{i t}\right)$ is the $\log$ of invested stock in USD (all property or offices as appropriate), $\log \left(g d p c_{i t}\right)$ is the $\log$ of GDP per capita in constant USD and $v a c_{i t}$ is office market vacancy rate as a proxy for real estate market conditions. Meanwhile, $s p r_{i t}$ is the bond yield spread, $f d i_{i t}$ is a net inward FDI measure, $b o p_{i t}$ is the change in the current account balance as a percentage of GDP and $i p r_{i t}$ is the property rights index (sub-index of IEF). ${ }^{6}$ Note that we do not use capitalisation rates as an independent variable in our models owing to the strong likelihood of simultaneity bias as indicated by previous research (see Fisher et al., 2009; Ling et al., 2009).

The model does not include annual time dummies as a lot of temporal variation is captured by the economic variables listed above. However, a dummy for the global financial crisis years, defined as 2008-2010, was found to be significant and contribute additional explanation of patterns in transaction activity $\left(g f c_{i t}\right)$. Meanwhile, to address any concerns around stationarity in our data set, we have conducted panel unit root tests. These tests produced desirable results (i.e. confirming stationarity) for variables with a complete or near-complete set of observations, but test results were weaker for variables where missing observations were more common. For

\footnotetext{
${ }^{6}$ Other variables that were tested during the model development stage included real rental growth rate and real rent ratio (in the place of vacancy rate), and domestic credit as a percentage of GDP. However, these variables performed poorly in terms of explaining variations and this may be a result of confounding inter-relationships.
} 
example, to achieve stationarity for the balance of payments variable, first differences were used in place of levels. We present the results of the unit root tests in an appendix.

We also investigated the extent to which the regressors included in the model were correlated. There was a strong and significant positive correlation between the property rights index and $\log$ of GDP per capita. For this reason, we orthogonalized the latter as follows:

$$
\log \left(\mathrm{gdpc}_{\mathrm{it}}\right)=\alpha_{0}+\beta_{1} \mathrm{ipr}_{\mathrm{it}}+\theta_{\mathrm{it}}
$$

Where $\hat{\theta}_{\text {it }}$, the residual term, is the orthogonalized $\log \left(g d p c_{i t}\right)$ against $i p r_{i t}$. We then incorporate $\hat{\theta}_{\text {it }}$ in equation (4) in the place of $\log \left(g d p c_{i t}\right)$.

For robustness purposes, we split the sample of countries into two groups: developed markets and emerging markets. Acknowledging that there is subjectivity in the criteria for categorising developed and emerging markets, we divide the countries according to their average GDP per capita (in constant USD) over the period, leaving two groups of 17 markets. In Europe, the developed markets are mostly in the west and north of the continent while the emerging markets are mainly the transition economies of Central and Eastern Europe. However, Spain was classified as emerging as well, lying just below the average GDP per capita for the sample of markets at hand. In Asia-Pacific, the developed markets include Japan, Australia, New Zealand, Hong Kong and Singapore, while the emerging markets include China, India, South Korea, Thailand and Malaysia. The regression models were re-estimated for these subsets to check if relationships found for the full sample remained stable.

\section{Findings}


We present the results of the econometric models for all commercial property and for the office sector turnover rates in Table 3. Model results are presented for all countries and then for the sub-samples of developed and emerging markets. Columns 1-3 in Table 3 present the outputs for the models using all property data, while Columns 4-6 present the outputs for the models using office sector data. Columns 1 and 4 show the full sample results in each case, with other columns showing developed or emerging market results as indicated.

The sample sizes are higher for all commercial property than for the office sector models since, as noted above, there were some countries where office turnover rates could not be measured. The all property models also benefit from an additional year of data for the turnover rates. Sample sizes are greater for the developed market models owing to better data availability relative to emerging markets both in the case of the dependent variable and some of the independent variables. The explanatory power of the models is broadly satisfactory with an adjusted R-squared of around $40-50 \%$ for most models. However, it is clear that there remains significant unexplained variation.

\section{INSERT TABLE 3 HERE}

A positive relationship was expected between market size and turnover rate owing to economies of scale and information network effects. Yet, with the exception of office markets in developed countries, we find an unexpected and statistically significant negative effect of market size on turnover rate. This may be explained by the fact that a number of smaller national markets contain major global destinations for real estate investment capital and have high turnover rates, e.g. Belgium/Brussels and Sweden/Stockholm. Hong Kong and Singapore 
are the most prominent examples here. This finding differs from that of Devaney, McAllister and Nanda (2017) who found a positive relationship between turnover and market size when studying different cities within a single nation, the US. ${ }^{7}$

The expected positive association between wealth and turnover rates is found. For developing and emerging markets, the coefficient for GDP per capita is significant and positive when all commercial property is considered. In the office sector, it is not significant for the sub-sample of developed markets, but it is strong for emerging markets. This suggests that there might be a non-linear relationship between wealth and transaction activity, with the effect of wealth on transaction activity decreasing for more mature markets. ${ }^{8}$ Similarly, Lieser and Groh (2014) found a positive association between GDP per capita and transaction volumes.

In terms of capital market conditions, the expected negative effect of sovereign bond yield spread on turnover rate is found. For all properties and for office properties, whether for the whole sample or the sub-samples of developed and emerging markets, there is a statistically significant negative relationship between bond yield spreads and turnover rates. Bearing in mind that sovereign bond yield spread is a portmanteau variable used to capture conditions in the broader capital markets, all else equal an increase in a country's bond yield relative to US bond yields is associated with a fall in turnover rates. This finding is consistent with the fact that the dummy variable for the time period of the Global Financial Crisis is also statistically significant and negative in several models. The exception is for emerging markets, which did not suffer the same degree of collapse in transaction activity in this period.

\footnotetext{
${ }^{7}$ It also differs from the finding in Lieser and Groh (2014) with respect to (economic) size. Since they modelled volumes and not turnover rates, this is not a surprise as volumes are not adjusted for sheer scale and higher volumes are likely in the largest economies.

${ }^{8}$ Note that as this variable was orthogonalized to deal with multicollinearity, the scaling and interpretation of the coefficients is less straightforward than for the other variables in the models.
} 
In terms of real estate market indicators, a similarly clear result is found for office vacancy rates. These are not interpreted as a driver in their own right, but are used as a proxy for demand and supply conditions in commercial real estate markets. For the whole sample and emerging market sub-sample, there is an expected, statistically significant negative relationship between vacancy rates and turnover rates. Thus, there tends to be a decline in turnover rates as vacancy rates increase (and real estate performance deteriorates). This result echoes that found for the US in Devaney, McAllister and Nanda (2017). Whilst there are also negative coefficients for the developed market sub-sample, surprisingly, these are not statistically significant. However, the significance of the GFC dummy in the case of developed markets suggests that the negative effects of the market downturn on transaction activity produced by changing market conditions were asymmetric.

Turning to the effect of property rights, we would expect a positive association between the rating in the property rights index and turnover rate. Lieser and Groh (2014) found volumes to be positively related to this measure. The expected positive relationship is generally found. In five out of six model results, we find an expected and significant positive relationship between quality of property rights and turnover rate. Similar to our findings for GDP per capita and market size, it is not significant for the developed country office markets, but it is strong for emerging markets. This is consistent with a non-linear relationship between market maturity and transaction activity, with the effect of market maturity decreasing for the most mature sector in the most mature markets.

In terms of the other explanatory variables included in the model, the results are less clear cut. Current account balance was included in the model specification in an attempt to capture the 
expectation that 'surplus' countries such as Germany, Japan, Norway and Switzerland would have limited turnover owing to scarcity of available stock for domestic investors. However, the results are inconclusive. While the coefficient signs are negative in all models, they are not significant and this might reflect the limitations of the proxy used or the transformation needed to make this variable stationary. Meanwhile, foreign direct investment was included to capture the level of global integration for each nation. The results here are also inconclusive. For all commercial property, the FDI coefficient is positive for emerging markets only and it does not attain statistical significance at even the $10 \%$ level. For the office sector, it is significant and positive for the whole sample and for developed markets.

Table 4 presents the estimated coefficients for the country fixed effects from the full sample models, with Australia as the hold-out category. For all commercial property, there are no significant country fixed effects for approximately one third of the markets. In each case, these markets are developed markets. For emerging markets, the coefficient on the country fixed effect is always significantly positive. The level of transaction activity tends to be higher in emerging markets than predicted by our determinants. From the developed markets, only the UK has a statistically significant positive coefficient and it is smaller in magnitude than those for most of the emerging markets. The remainder of the developed countries have statistically significant negative fixed effects coefficients. So the level of transaction activity in developed markets tends to be in line with or lower than predicted by fundamentals. The findings remain broadly the same in respect of the office turnover rates.

INSERT TABLE 4 HERE 
This strong pattern suggests that the fixed effects are capturing the effect of omitted variables. One possibility not reflected by our independent variables is transaction costs. Whilst transfer taxes and other direct transaction costs are likely to affect transaction activity, the evidence suggests that direct transaction costs are not strongly related to whether a market is classified as developed, emerging or even frontier (Devaney, Livingstone, McAllister and Nanda, 2016). A more likely explanation is that the larger importance of newly built stock in emerging markets increases transaction activity in a mechanistic manner as developers realize profits by selling to investors as projects are completed. It is also possible that the marginal effect of the explanatory variables is non-linear and that an identical improvement for a variable, e.g. security of property rights or GDP per capita, has different impacts on transaction activity in emerging markets when compared to relatively wealthy, developed markets with strong property rights and higher levels of market maturity.

\section{Conclusion}

Numerous studies have identified a clear association between changes in prices and transaction activity in real estate markets. Complex causality patterns involving the interaction of market conditions, feedback effects, behavioral biases, clientele effects and credit cycles have been proposed as co-determining temporal variations in transaction activity and price levels. Almost certainly owing to limited data availability, differences in transaction volumes and turnover rates between markets - particularly international markets - have been largely neglected. Cross-sectional variations in transaction activity may reflect differences in institutional as well as market factors. In particular, it is expected that the propensity of market participants to transact will be affected by direct and indirect transaction costs and risks. As local institutional constructs, national commercial real estate markets vary in terms of transfer taxes, efficiency 
of execution, security of property rights, and brokerage costs and models. The investment horizons of marginal investors can also affect the propensity to transact. For instance, it is likely that the higher the proportion of new stock that is being developed, the higher will be the level of transaction activity as developers exit projects by selling assets to investors.

The findings of this study broadly confirm our expectations. The link between transaction activity, prices and market conditions is particularly apparent from the spike in transaction activity during the commercial real estate price bubble of 2006-7 and the subsequent plunge in values and volumes in 2008-9 as the global financial crisis took hold. The results of the formal econometric analysis are consistent with this pattern in that a negative relationship between market risk (as proxied by spreads in sovereign bond yields) and turnover rates is found. Furthermore, there appears to be a drop in turnover beyond what might be expected for the years 2008-10, as captured by our GFC dummy variable for these years. More broadly, it is found that there are positive associations between the level of transaction activity in a market and its economic prosperity, global economic integration, market maturity and commercial real estate occupancy rates.

This first attempt to explore cross-country variations in turnover rates illustrates the complexities and challenges of measuring and explaining differences in transaction activity between different markets and in different market conditions. The unexpected finding for market size may suggest that, with the obvious requirement for appropriate data, the optimal scale of analysis for future research is at the city rather than the country level. The notable differences in fixed effects coefficients between developed and emerging markets suggest that the drivers of turnover in each case vary and this could merit further investigation as well. Finally, though it is widely used as a proxy for liquidity, it is worth re-iterating that transaction 
activity is not a 'pure' measure of liquidity. While high levels of transaction activity require the ability to transact, it is not axiomatic that low levels of transaction activity reflect an inability to sell at the prevailing market price within a reasonable timeframe. There is scope for further investigation in this regard.

\section{Appendix}

\section{INSERT APPENDIX TABLE 1 HERE}

\section{References}

Anglin, P., Rutherford, R. and Springer, T. (2003). The trade-off between the selling price of residential properties and time-on-the-market: The impact of price setting. The Journal of Real Estate Finance and Economics, 26(1), 95-111.

Chervachidze, S. and Wheaton, W. (2013). What Determined the Great Cap Rate Compression of 2000-2007, and the Dramatic Reversal During the 2008-2009 Financial Crisis? Journal of Real Estate Finance and Economics, 46 (2), 208-231.

Chin, H. and Dent, P. (2005). An Analysis of the Level of Maturity in South-East Asian Property Markets. Pacific Rim Property Research Journal, 11 (4), 355-372.

Chin, W., Dent, P. and Roberts, C. (2006). An Exploratory Analysis of Barriers to Investment and Market Maturity in Southeast Asian Cities. Journal of Real Estate Portfolio Management, 12 (1), 49-57.

Clayton, J., MacKinnon, G. and Peng L. (2008), Time variation of liquidity in the private real estate market: An empirical investigation. Journal of Real Estate Research, 30 (2), 125 160. 
Constantinides, G. (1997). Transactions costs and the pricing of financial assets. Multinational Finance Journal, 1 (2), 93-99.

Devaney, S., Livingstone, N., McAllister, P. and Nanda, A. (2017). Institutional Convergence in Real Estate Markets: A Comparative Study of Brokerage Models and Transaction Costs. Journal of Real Estate Literature, 25 (1), 169-188.

Devaney, S., McAllister, P. and Nanda, A. (2017). Which Factors Determine Transaction Activity across US Metropolitan Office Markets? Journal of Portfolio Management.

DTZ (2015), Money into Property 2015, DTZ. London.

Fisher, J., Gatzlaff, D., Geltner, D. and Haurin, D. (2003). Controlling for the Impact of Variable Liquidity in Commercial Real Estate Price Indices. Real Estate Economics, 31 (2), 269-303.

Fisher, J., Gatzlaff, D., Geltner, D. and Haurin, D. (2004). An Analysis of the Determinants of Transaction Frequency of Institutional Commercial Real Estate Investment Property. Real Estate Economics, 32 (2), 239-264.

Fisher, J., Ling, D. and Naranjo, A. (2009). Institutional Capital Flows and Return Dynamics in Private Commercial Real Estate Markets. Real Estate Economics, 37 (1), 85-116.

Gallant, R., Rossi, P. and Tauchen, G. (1992) Stock prices and volume, Review of Financial Studies, 5, 199-242.

Goetzmann, W. and Peng, L. (2006). Estimating house price indexes in the presence of seller reservation prices. The Review of Economics and Statistics, 88 (1), 100-112.

Keogh, G. and D’Arcy, E. (1994). Market maturity and property market behaviour: A European comparison of mature and emergent markets. Journal of Property Research, 11 (3), 215235.

Krainer, J. (2001). A Theory of Liquidity in Residential Real Estate Markets. Journal of Urban Economics, 49, 32-53. 
Lieser, K. and Groh, A. (2011). The Attractiveness of 66 Countries for Institutional Real Estate Investments. Journal of Real Estate Portfolio Management, 17 (3), 191-211.

Lieser, K. and Groh, A. (2014). The Determinants of International Commercial Real Estate Investment. Journal of Real Estate Finance and Economics, 48 (4), 611-659.

Ling, D., Marcato G. and McAllister P. (2009). The dynamics of asset prices, capital flows, and transaction activity in illiquid, informational inefficient, commercial real estate markets. Journal of Real Estate Finance and Economics, 39 (3), 359-383.

Mauck, N. and Price, S. (2017). Determinants of Foreign Versus Domestic Real Estate Investment: Property Level Evidence from Listed Real Estate Investment Firms. Journal of Real Estate Finance and Economics, 54(1), 17-57.

McGreal, S., Parsa, A. and Keivani, R. (2002). Evolution of property investment markets in Central Europe: opportunities and constraints. Journal of Property Research, 19 (3), 213 230.

MSCI (2015). IPD Global Annual Property Index: Results for the year to 31 December 2014. London: MSCI.

Ortalo-Magne', F. and Rady. S. (2006) Housing Market Dynamics: On the Contribution of Income Shocks and Credit Constraints. Review of Economic Studies, 73, 459-85. 
Figure 1: Determinants of Real Estate Market Transaction Activity

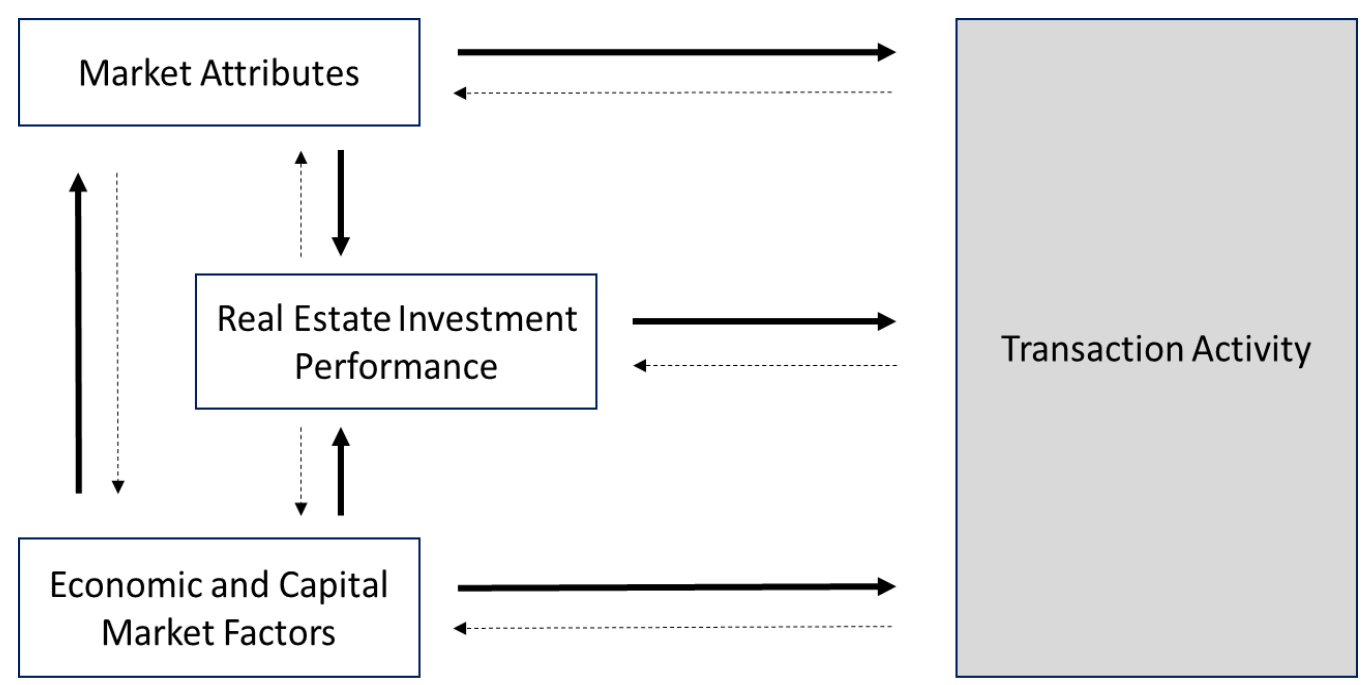


Figure 2: European office turnover rates and prime office capitalization rates, 2001-14

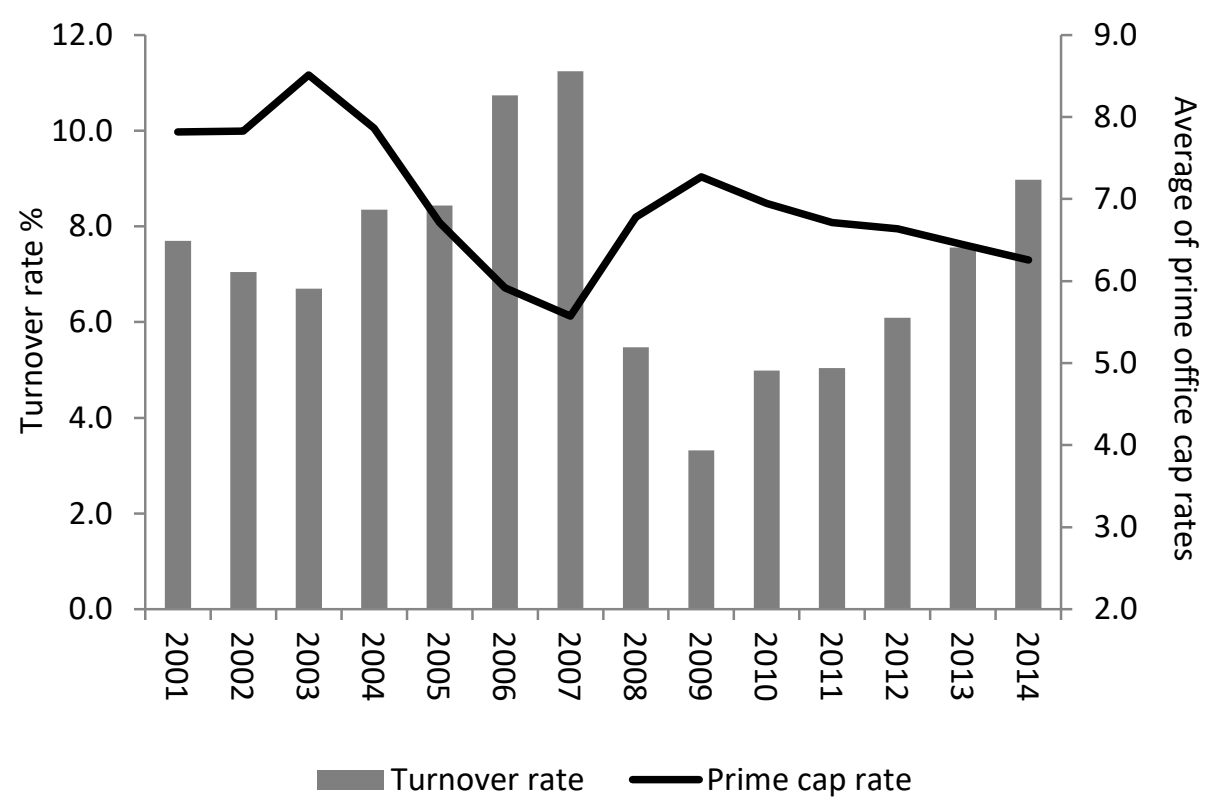

Source: DTZ, own calculations

Figure 3: Asia-Pacific office turnover rates and prime office capitalization rates, 2001-14

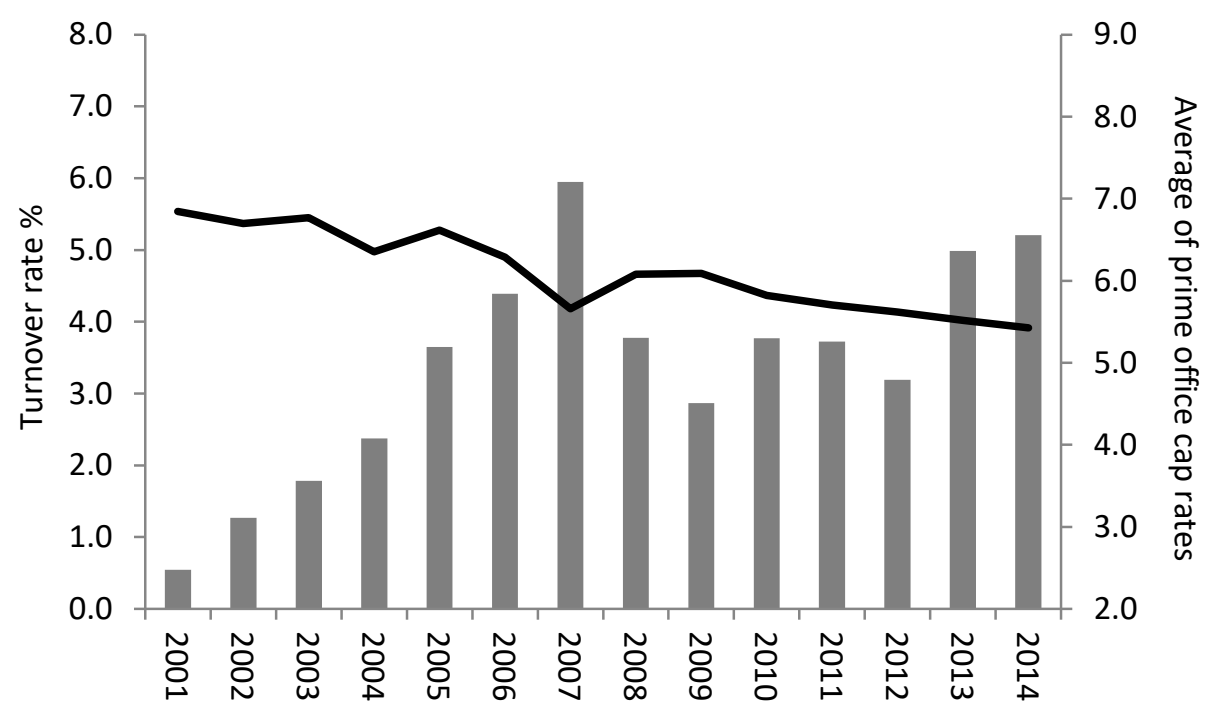

Turnover rate $\longrightarrow$ Prime cap rate

Source: DTZ, own calculations 
Table 1: Mean values for turnover rates and other real estate indicators, by country.

\begin{tabular}{|c|c|c|c|c|c|c|}
\hline & \multicolumn{2}{|c|}{ All sectors (2000-14) } & \multicolumn{4}{|c|}{ Office sector $(2001-14)$} \\
\hline & $\begin{array}{l}\text { Turnover } \\
\text { rate }(\%)\end{array}$ & $\begin{array}{c}\text { Invested } \\
\text { stock (\$ bn) }\end{array}$ & $\begin{array}{l}\text { Turnover } \\
\text { rate }(\%)\end{array}$ & $\begin{array}{c}\text { Invested } \\
\text { stock (\$ bn) }\end{array}$ & $\begin{array}{l}\text { Vacancy } \\
\text { rate }(\%)\end{array}$ & $\begin{array}{c}\text { Prime cap } \\
\text { rate }(\%)\end{array}$ \\
\hline Australia & 3.2 & 293.2 & 3.6 & 136.0 & 7.3 & 6.9 \\
\hline China & 1.0 & 667.6 & 7.5 & 71.5 & 12.9 & 6.7 \\
\hline Hong Kong & 2.8 & 156.4 & 4.3 & 51.0 & 6.8 & 4.5 \\
\hline India & 2.7 & 20.7 & 4.5 & 6.8 & - & 8.8 \\
\hline Japan & 1.3 & $1,154.2$ & 2.1 & 441.1 & 6.0 & 4.9 \\
\hline Malaysia & 2.6 & 43.1 & 4.1 & 12.7 & 14.6 & 7.4 \\
\hline New Zealand & 2.3 & 29.6 & 3.0 & 11.2 & - & - \\
\hline Singapore & 7.0 & 84.6 & 8.9 & 24.8 & 7.4 & 3.9 \\
\hline South Korea & 3.1 & 114.1 & 8.5 & 34.6 & 5.1 & 6.7 \\
\hline Taiwan & 2.9 & 76.3 & 4.9 & 24.1 & 10.1 & 4.7 \\
\hline Thailand & 2.0 & 20.8 & 4.2 & 2.9 & 14.0 & 7.8 \\
\hline Austria & 1.8 & 42.8 & - & 9.2 & - & - \\
\hline Belgium & 5.8 & 59.0 & 12.2 & 16.6 & 9.9 & 6.3 \\
\hline Czech Republic & 4.5 & 26.5 & 11.8 & 5.3 & 11.5 & 7.1 \\
\hline Denmark & 3.2 & 45.3 & 4.4 & 11.3 & 7.1 & 5.6 \\
\hline Estonia & 0.3 & 4.9 & - & 1.0 & 12.4 & 8.1 \\
\hline Finland & 3.3 & 42.6 & 3.8 & 10.7 & 11.2 & 5.7 \\
\hline France & 4.0 & 514.4 & 7.4 & 172.7 & 5.8 & 5.9 \\
\hline Germany & 4.7 & 504.8 & 6.6 & 122.8 & 8.7 & 5.1 \\
\hline Greece & 2.5 & 11.8 & - & 4.5 & - & - \\
\hline Hungary & 2.5 & 23.7 & 5.9 & 5.7 & 18.1 & 7.7 \\
\hline Ireland & 3.1 & 55.4 & 3.9 & 14.4 & 16.6 & 5.6 \\
\hline Italy & 2.8 & 263.1 & 3.1 & 75.5 & 7.6 & 5.1 \\
\hline Latvia & 0.2 & 6.0 & - & 1.4 & 13.3 & 8.4 \\
\hline Lithuania & 0.7 & 3.4 & - & 0.5 & 8.5 & 9.0 \\
\hline Luxembourg & 5.8 & 12.7 & - & 5.9 & 4.5 & 6.1 \\
\hline Netherlands & 3.7 & 204.0 & 6.3 & 57.4 & 13.3 & 6.4 \\
\hline Norway & 4.4 & 73.0 & 8.6 & 21.6 & 7.6 & 5.9 \\
\hline Poland & 4.9 & 43.8 & 13.8 & 6.5 & 10.0 & 7.3 \\
\hline Portugal & 1.7 & 36.6 & - & 9.3 & - & - \\
\hline Romania & 1.8 & 26.4 & 2.4 & 5.4 & 9.7 & 8.4 \\
\hline Russia & 2.9 & 68.7 & 7.6 & 11.5 & 9.6 & 12.2 \\
\hline Spain & 2.7 & 339.4 & 4.2 & 87.5 & 8.0 & 5.6 \\
\hline Sweden & 8.9 & 113.4 & 14.4 & 25.8 & 10.5 & 5.5 \\
\hline Switzerland & 0.4 & 139.9 & - & 29.8 & 6.8 & 4.3 \\
\hline Turkey & 1.7 & 17.1 & - & 3.7 & 11.8 & 8.8 \\
\hline Ukraine & 1.0 & 8.6 & - & - & 11.2 & 13.6 \\
\hline United Kingdom & 8.5 & 777.0 & 11.1 & 249.8 & 7.4 & 5.7 \\
\hline
\end{tabular}

Source of variables: DTZ, own calculations (see text). Not all countries can produce a figure for every year and so the figures are broadly comparable, but not precisely comparable. 
Table 2: Mean values for economic indicators and property rights index, by country

\begin{tabular}{|c|c|c|c|c|c|c|}
\hline & \multicolumn{6}{|c|}{ Economy (2000-2014) } \\
\hline & $\begin{array}{c}\text { GDP }(\$ \\
\text { bn) }\end{array}$ & $\begin{array}{l}\text { GDP per } \\
\text { capita }(\$)\end{array}$ & $\begin{array}{c}\text { Bond spread } \\
\text { vs US (\%) }\end{array}$ & $\begin{array}{c}\text { BOP (\% } \\
\text { GDP) }\end{array}$ & $\begin{array}{l}\text { Net FDI } \\
(\% \text { GDP })\end{array}$ & $\begin{array}{c}\text { Property } \\
\text { Rights }\end{array}$ \\
\hline Australia & 909 & 34,740 & 1.3 & -4.7 & 3.3 & 90.0 \\
\hline China & 4,505 & 2,301 & 0.8 & 4.1 & 3.5 & 24.7 \\
\hline Hong Kong & 211 & 28,274 & -0.2 & 7.9 & 25.8 & 90.0 \\
\hline India & 1,182 & 854 & 4.5 & -1.4 & 1.6 & 50.0 \\
\hline Japan & 4,792 & 35,805 & -2.6 & 2.8 & 0.2 & 76.0 \\
\hline Malaysia & 199 & 5,925 & -0.1 & 10.7 & 3.2 & 52.3 \\
\hline New Zealand & 124 & 27,592 & 1.5 & -4.0 & 1.9 & 92.0 \\
\hline Singapore & 183 & 31,225 & -1.0 & 18.8 & 17.3 & 90.0 \\
\hline South Korea & 955 & 20,024 & 1.2 & 2.4 & 0.9 & 74.0 \\
\hline Taiwan & 404 & 18,055 & -1.5 & 7.4 & - & 72.7 \\
\hline Thailand & 259 & 3,069 & 0.6 & 2.5 & 3.1 & 53.7 \\
\hline Austria & 341 & 39,149 & -0.1 & 2.6 & 4.4 & 90.0 \\
\hline Belgium & 417 & 37,052 & 0.1 & 1.1 & 13.2 & 84.7 \\
\hline Czech Republic & 160 & 13,603 & 0.1 & -2.9 & 5.0 & 69.3 \\
\hline Denmark & 279 & 47,974 & -0.2 & 3.8 & 2.6 & 90.3 \\
\hline Estonia & 17 & 10,314 & 2.4 & -6.0 & 9.3 & 78.3 \\
\hline Finland & 220 & 38,795 & -0.2 & 3.7 & 3.1 & 90.3 \\
\hline France & 2,324 & 34,970 & -0.1 & -0.1 & 2.2 & 73.3 \\
\hline Germany & 3,074 & 36,397 & -0.4 & 4.4 & 2.2 & 90.0 \\
\hline Greece & 246 & 21,213 & 3.6 & -7.8 & 0.8 & 52.0 \\
\hline Hungary & 112 & 10,877 & 3.5 & -3.8 & 10.0 & 68.3 \\
\hline Ireland & 206 & 49,129 & 1.0 & -0.4 & 16.8 & 90.0 \\
\hline Italy & 1,885 & 31,139 & 0.7 & -1.3 & 1.0 & 58.3 \\
\hline Latvia & 22 & 7,711 & 2.2 & -6.7 & 3.9 & 51.0 \\
\hline Lithuania & 32 & 8,393 & 1.9 & -5.0 & 3.0 & 53.0 \\
\hline Luxembourg & 44 & 80,082 & -0.4 & 8.2 & 32.4 & 90.0 \\
\hline Netherlands & 725 & 42,392 & -0.2 & 6.5 & 24.0 & 90.0 \\
\hline Norway & 360 & 65,845 & 0.0 & 13.1 & 2.9 & 90.0 \\
\hline Poland & 377 & 8,941 & 2.3 & -4.1 & 3.4 & 58.3 \\
\hline Portugal & 202 & 18,749 & 1.6 & -7.6 & 4.1 & 70.0 \\
\hline Romania & 130 & 5,069 & 3.2 & -6.2 & 4.0 & 33.7 \\
\hline Russia & 1,150 & 5,704 & 7.3 & 7.2 & 2.5 & 30.7 \\
\hline Spain & 1,197 & 25,908 & 0.6 & -4.4 & 3.4 & 70.0 \\
\hline Sweden & 431 & 43,282 & -0.2 & 6.6 & 3.7 & 89.0 \\
\hline Switzerland & 489 & 56,261 & -1.8 & 10.7 & 4.1 & 90.0 \\
\hline Turkey & 554 & 7,348 & 6.5 & -4.5 & 1.7 & 52.7 \\
\hline Ukraine & 110 & 1,845 & - & -0.5 & 4.0 & 30.0 \\
\hline United Kingdom & 2,362 & 39,382 & 0.2 & -2.7 & 4.0 & 89.3 \\
\hline
\end{tabular}

Source of variables: World Bank, IMF, The Heritage Foundation. Not all countries can produce a figure for every year and so the figures are broadly comparable, but not precisely comparable. GDP per capita is in 2005 US dollar terms. 
Table 3: Results from panel data models of commercial real estate turnover rates

\begin{tabular}{|c|c|c|c|c|c|c|}
\hline & \multicolumn{3}{|c|}{ All Property: 2000-2014 } & \multicolumn{3}{|c|}{ Office Property: 2001-14 } \\
\hline & (1) & (2) & (3) & (4) & (5) & (6) \\
\hline & $\begin{array}{l}\text { Full sample } \\
\text { of markets }\end{array}$ & $\begin{array}{l}\text { Developed } \\
\text { markets }\end{array}$ & $\begin{array}{l}\text { Emerging } \\
\text { markets }\end{array}$ & $\begin{array}{l}\text { Full sample } \\
\text { of markets }\end{array}$ & $\begin{array}{l}\text { Developed } \\
\text { markets }{ }^{\#}\end{array}$ & $\begin{array}{l}\text { Emerging } \\
\text { markets }\end{array}$ \\
\hline Log(Invested stock in USD) & $\begin{array}{l}-1.671 * * * \\
(-3.30)\end{array}$ & $\begin{array}{l}-2.402 * * * \\
(-2.67)\end{array}$ & $\begin{array}{l}-2.130 * * * \\
(-3.04)\end{array}$ & $\begin{array}{l}-2.400 * * \\
(-2.27)\end{array}$ & $\begin{array}{l}-1.137 \\
(-0.58)\end{array}$ & $\begin{array}{l}-3.594 * * \\
(-2.16)\end{array}$ \\
\hline $\log (\text { GDP per capita in USD })^{+}$ & $\begin{array}{l}10.92 * * * \\
(4.77)\end{array}$ & $\begin{array}{l}22.99 * * * \\
(2.87)\end{array}$ & $\begin{array}{l}8.945 * * * \\
(3.73)\end{array}$ & $\begin{array}{l}17.77 * * * \\
(3.23)\end{array}$ & $\begin{array}{l}15.15 \\
(1.23)\end{array}$ & $\begin{array}{l}20.93 * * * \\
(3.17)\end{array}$ \\
\hline Office vacancy rate & $\begin{array}{l}-0.233 * * * \\
(-3.77)\end{array}$ & $\begin{array}{l}-0.106 \\
(-0.99)\end{array}$ & $\begin{array}{l}-0.191 * * * \\
(-3.07)\end{array}$ & $\begin{array}{l}-0.342 * * * \\
(-3.28)\end{array}$ & $\begin{array}{l}-0.348 \\
(-1.52)\end{array}$ & $\begin{array}{l}-0.326 * * \\
(-2.19)\end{array}$ \\
\hline Bond yield spread vs. US & $\begin{array}{l}-0.545^{* * * *} \\
(-4.09)\end{array}$ & $\begin{array}{l}-0.534 * * \\
(-2.54)\end{array}$ & $\begin{array}{l}-0.513 * * * \\
(-3.44)\end{array}$ & $\begin{array}{l}-1.104 * * * \\
(-3.81)\end{array}$ & $\begin{array}{l}-0.825 * * \\
(-2.41)\end{array}$ & $\begin{array}{l}-1.351 * * * \\
(-3.14)\end{array}$ \\
\hline Change in balance of payments & $\begin{array}{l}-0.045 \\
(-0.86)\end{array}$ & $\begin{array}{l}-0.024 \\
(-0.29)\end{array}$ & $\begin{array}{l}-0.026 \\
(-0.45)\end{array}$ & $\begin{array}{l}-0.058 \\
(-0.50)\end{array}$ & $\begin{array}{l}-0.038 \\
(-0.24)\end{array}$ & $\begin{array}{l}-0.073 \\
(-0.39)\end{array}$ \\
\hline Net inward FDI (as \% GDP) & $\begin{array}{l}-0.034 \\
(-0.74)\end{array}$ & $\begin{array}{l}-0.044 \\
(-0.90)\end{array}$ & $\begin{array}{l}0.034 \\
(1.13)\end{array}$ & $\begin{array}{l}0.060 * * \\
(2.34)\end{array}$ & $\begin{array}{l}0.060 * \\
(1.92)\end{array}$ & $\begin{array}{l}0.050 \\
(0.96)\end{array}$ \\
\hline Property rights (sub-index of IEF) & $\begin{array}{l}0.463 * * * \\
(4.26)\end{array}$ & $\begin{array}{l}0.991 * * * \\
(2.95)\end{array}$ & $\begin{array}{l}0.311 * * \\
(2.38)\end{array}$ & $\begin{array}{l}0.774 * * * \\
(3.19)\end{array}$ & $\begin{array}{l}0.667 \\
(1.30)\end{array}$ & $\begin{array}{l}0.927 * * * \\
(2.68)\end{array}$ \\
\hline GFC period dummy (2008-2010) & $\begin{array}{l}-0.908 * * * \\
(-3.67)\end{array}$ & $\begin{array}{l}-1.193 * * * \\
(-3.58)\end{array}$ & $\begin{array}{l}-0.482 \\
(-1.41)\end{array}$ & $\begin{array}{l}-1.054 * \\
(-1.72)\end{array}$ & $\begin{array}{l}-1.989 * * * \\
(-2.77)\end{array}$ & $\begin{array}{l}0.140 \\
(0.14)\end{array}$ \\
\hline Constant & $\begin{array}{l}-24.84 * * * \\
(-3.04)\end{array}$ & $\begin{array}{l}-67.56^{* * *} \\
(-2.61)\end{array}$ & $\begin{array}{l}-9.056 \\
(-1.21)\end{array}$ & $\begin{array}{l}-48.10^{* * *} \\
(-2.67)\end{array}$ & $\begin{array}{l}-45.01 \\
(-1.20)\end{array}$ & $\begin{array}{l}-50.71 * * \\
(-2.16)\end{array}$ \\
\hline Country fixed effects & YES & YES & YES & YES & YES & YES \\
\hline Goodness of fit: Adj. $\mathrm{R}^{2}$ & $49.3 \%$ & $48.3 \%$ & $50.1 \%$ & $44.8 \%$ & $47.4 \%$ & $39.3 \%$ \\
\hline Number of observations & 337 & 207 & 130 & 299 & 184 & 115 \\
\hline
\end{tabular}

Note: Robust standard errors are computed and t-statistics are reported within parentheses. ${ }^{*} * *<<0.01$; $*^{*} p<0.05 ; * p<0.1{ }^{+}$Variable is orthogonalised as per discussion in text. "Developed market list: Australia, Austria, Belgium, Denmark, Finland, France, Germany, Hong Kong, Ireland, Italy, Japan, Luxembourg, Netherlands, New Zealand, Norway, Singapore, Sweden, Switzerland, United Kingdom. \#\#Emerging market list: China, Czech Republic, Estonia, Greece, Hungary, India, Latvia, Lithuania, Malaysia, Poland, Portugal, Romania, Russia, South Korea, Spain, Thailand, Turkey, Ukraine. 
Table 4: Fixed effects from full sample models of turnover rates

\begin{tabular}{|c|c|c|}
\hline & (1) & $(2)$ \\
\hline & $\begin{array}{l}\text { All sectors } \\
2000-2014\end{array}$ & $\begin{array}{c}\text { Offices } \\
2000-2014\end{array}$ \\
\hline Australia & \multicolumn{2}{|c|}{ Omitted country } \\
\hline Belgium & -1.191 & 0.488 \\
\hline China & $27.38 * * *$ & $49.82 * * *$ \\
\hline Czech Republic & $7.672 * * *$ & $17.06 * * *$ \\
\hline Denmark & $-7.483 * * *$ & $-12.10 * * *$ \\
\hline Finland & $-3.333 * *$ & $-6.813 * *$ \\
\hline France & 0.153 & $2.415^{*}$ \\
\hline Germany & 1.533 & 0.821 \\
\hline Hong Kong & 0.544 & -1.641 \\
\hline Hungary & $11.51 * * *$ & $21.19 * * *$ \\
\hline Ireland & $-3.874 * *$ & $-8.212 *$ \\
\hline Italy & 0.051 & 0.304 \\
\hline Japan & $-2.204 *$ & -2.787 \\
\hline Latvia & $6.072 * *$ & - \\
\hline Lithuania & $6.206^{* *}$ & - \\
\hline Luxembourg & $-11.84 * * *$ & - \\
\hline Malaysia & $16.45 * * *$ & $27.85^{* * *}$ \\
\hline Netherlands & -1.322 & -3.546 \\
\hline Norway & $-8.292 * * *$ & $-11.35 * *$ \\
\hline Poland & $14.35 * * *$ & $29.20 * * *$ \\
\hline Romania & $17.62 * * *$ & $28.95 * * *$ \\
\hline Russia & $20.59 * * *$ & $38.90 * * *$ \\
\hline Singapore & 2.832 & 0.042 \\
\hline South Korea & $2.546^{*}$ & $9.280 * * *$ \\
\hline Spain & $2.275^{*}$ & $4.463 * *$ \\
\hline Sweden & 1.681 & 2.409 \\
\hline Switzerland & $-10.94 * * *$ & - \\
\hline Thailand & $21.16^{* * *}$ & $36.26 * * *$ \\
\hline Turkey & $12.04 * * *$ & - \\
\hline United Kingdom & $4.733 * * *$ & $5.720 * * *$ \\
\hline
\end{tabular}

Note: Robust standard errors are computed and t-statistics are reported within parentheses. $* * * p<0.01$; $* * p<0.05 ; * p<0.1$. Countries omitted from the final estimations owing to availability of variables are Austria, Estonia, Greece, India, New Zealand, Portugal, Taiwan and Ukraine. 
Table A1: Results from Fisher-type panel unit root tests

\begin{tabular}{l|c}
\hline \hline & p-value \\
\hline Liquidity ratio: all commercial property & $0.002 * * *$ \\
Liquidity ratio: office sector & $0.002 * * *$ \\
Log(All property invested stock in USD) & $0.000^{* * *}$ \\
Log(Office sector invested stock in USD) & \\
Log(GDP per capita in USD) ${ }^{+}$ & $0.000^{* * *}$ \\
Office vacancy rate & $0.000^{* * *}$ \\
Bond yield spread vs. US & $0.000^{* * *}$ \\
Change in balance of payments as \% GDP & \\
Net inward FDI as \% GDP & $0.000^{* * *}$ \\
Property rights (sub-index of IEF) & $0.087 *$ \\
\hline
\end{tabular}

Note: Based on augmented Dickey-Fuller tests. Null hypothesis is that a unit root exists for the series. $* * * p<0.01 ; * * p<0.05 ; * p<0.1 .{ }^{+}$Variable is orthogonalised as per discussion in text. 